\title{
Desa Wirausaha sebagai Eskalasi Ekonomi Desa berbasis Kewirausahaan
}

\author{
Oleh: \\ Agung Purnomo \\ Universitas Bina Nusantara \\ agung.purnomo@binus.ac.id
}

\section{Pengantar}

Dinamika ekonomi di desa seringkali dianggap lebih lamban alih-alih pertumbuhan ekonomi di kota. Strukturisasi dan eskalasi ekonomi desa dapat dikerjakan dengan cara memberdayakan sumber daya yang tersedia dan dimiliki oleh di suatu desa secara efisien, efektif dan bijaksana. Kegiatan pemberdayaan ini perlu dilaksanakan berdasarkan situasi dan kondisi lingkungan desa serta kebutuhan masyarakat desa demi tercapainya kesejahteraan dan kemakmuran bagi masyarakat desa secara merata dan berkesinambungan (Kusuma and Purnamasari, 2016).

Pemanfaatan sumberdaya alam dapat diwujudkan menggunakan dua metode, yakni: a) kesadaran kolektif masyarakat untuk melaksanakan perubahan yang lestari dan tindakan pencegahan terhadap kegiatan yang deskonstruktif; dan b) kebijakan pemerintah desa yang didukung masyarakat untuk mewujudkan pembangunan berkelanjutan sesuai perencanaan terpadu (Bachrein, 2016).

Kekuatan potensi terpendam sumberdaya belum didayagunakan dengan optimal selama ini. Banyak pemanfaatan sumberdaya alam di Indonesia 
tendensius eksploitatif tanpa memperhatikan implikasi negatif kepada lingkungan dan masyarakat.

Salah satu pendekatan solutif untuk mengakselerasi eskalasi perekonomian di desa adalah implementasi gerakan kewirausahaan secara kolektif oleh segenap warga desa dalam bentuk desa wirausaha. Kewirausahan sebagai strategi untuk pertumbuhan dan pengembangan terhadap kesejahteraan dan kemakmuran suatu masyarakat desa berbasis keberadaan sumber daya serta akses fasilitas dan prasarana representatif yang diberikan oleh komunitas masyarakat desa guna meraih perubahan positif suatu kondisi sosial ekonomi di pedesaan (Ansari et al., 2013). Kewirausahaan terbukti dapat sebagai solusi bagi masyarakat untuk menyelesaikan ragam masalah (Purnomo et al., 2020). Perkembangan ekonomi pedesaan dapat didorong oleh keberadaan desa wirausaha yang bertransformasi menjadi suatu gerakan dan aktivitas kesadaran yang masif. Kehadiran desa wirausaha yang produktif dapat berpotensi untuk menstimulasi perkembangan dan pertumbuhan ekonomi di desa secara nyata dan implementatif.

Badan Usaha Milik Desa (BUMDes) merupakan suatu perusahaan yang dioperasikan secara mandiri oleh warga suatu desa dan pengelolanya perlu terpisah dari struktur resmi operasional pemerintah desa. Lembaga bernama BUMDes hadir dengan visi guna memberdayakan serta mengoptimalkan segenap potensi dan kekuatan nyata wirausaha desa. Badan Usaha Milik Desa berdiri atas landasan legalitas Undang-Undang Nomor 32 Tahun 2004 mengenai Pemerintahan Daerah Pasal 213 ayat (1) memaparkan tentang "Desa dapat mendirikan badan usaha milik desa sesuai dengan kebutuhan dan potensi desa" sebagai fundamental esensial untuk komitmen pendirian suatu BUMDes. BUMDes dalam Undang-Undang Desa dimaknai sebagai suatu badan usaha yang sebagian besar atau seluruh kapitalnya dimiliki oleh desa secara langsung melalui penyertaan yang berasal dari pemisahan kekayaan desa tatkala mengoperasionalkan beberapa jasa pelayanan, aset, serta wirausahan lainnya demi sebesar-besarnya kemakmuran, keadilan sosial, serta kesejahteraan masyarakat suatu desa (Presiden Republik Indonesia, 2016).

Pembangunan suatu desa dapat terus dioptimalkan melalui pengembangan dan peningkatan segenap potensi perekonomian desa. Juga, sebagai komunitas dan bentuk kolektif masyarakat pedesaan dalam kemandirian mengembangkan diri dan lingkungan sekitar secara partisipatif. Program desa wirausaha sebagai tindakan dan langkah guna memunculkan dan memberdayakan potensi suatu wilayah sehingga dapat menggerakkan laju perekonomian suatu desa. Lembaga atau organisasi selain BUMDes yang banyak berperan dalam pengembangan 
desa wirausaha adalah koperasi dan UKM di desa (Fitriyani et al., 2018; Hastuti et al., 2020).

Desa wirausaha perlu digerakkan oleh para wirausahawan muda di desa. Para wirausaha muda desa sebagai agen penggerak solusi aktual terhadap permasalahan sosial di desa. Kapabilitas para pemuda untuk memobilisasi segenap komponen masyarakat di desa merupakan elemen esensial pada upaya rencana, upaya, dan proses menggerakkan partisipasi dan memberdayakan keterlibatan warga desa guna membangun dan memajukan suatu desa (Puspitasari, 2018).

\section{Definisi}

Kewirausahaan desa (rural entrepreneurship/ urban entrepreneurship) sebagai tindakan dan sikap mengorganisir seluruh komponen struktur ekonomi suatu pedesaan menggunakan segenap aset suatu desa seperti tenaga kerja, lingkungan, air serta tanah sebagai basis modal pengembangan wirausaha baru yang dioperasionalkan kolaboratif oleh segenap elemen suatu desa (Kusuma and Purnamasari, 2016).

Kewirausahaan desa juga dapat dimaknai sebagai pengembangan usaha baru yang memelopori produk dan layanan baru, menciptakan pasar baru untuk penawarannya atau menggunakan teknologi canggih di daerah pedesaan. Kewirausahaan yang muncul di daerah non-perkotaan (Business Jargons, 2021).

Desa wirausaha merupakan suatu desa yang melaksanakan kewirausahaan secara terorganisir oleh segenap komponen desa.

\section{Manfaat Desa Wirausaha}

Eskalasi desa wirausaha dapat menawarkan beberapa manfaat solusi sebagai berikut.

1. Mengurangi kemiskinan di desa (Kusuma and Purnamasari, 2016);

2. Meningkatkan kualitas pelayanan sosial di desa (Puspitasari, 2018);

3. Mereduksi urbanisasi penduduk dari desa ke kota (Kusuma and Purnamasari, 2016);

4. Menjaga budaya tradisional nenek moyang (Thakur, 2021);

5. Membuka lapangan kerja di desa (Kusuma and Purnamasari, 2016); 
6. Memanfaatkan sumberdaya secara tepat, lestari dan berkesinambungan (Thakur, 2021);

7. Mengakselerasi pendapatan masyarakat desa (Kusuma and Purnamasari, 2016);

8. Menurunkan kesenjangan antara desa dengan kota (Thakur, 2021);

9. Menambah diversifikasi jenis wirausaha di desa (Kusuma and Purnamasari, 2016);

10. Memperkuat merek agar nama desa lebih dikenal luas (Kusuma et al., 2020; Saputra et al., 2020).

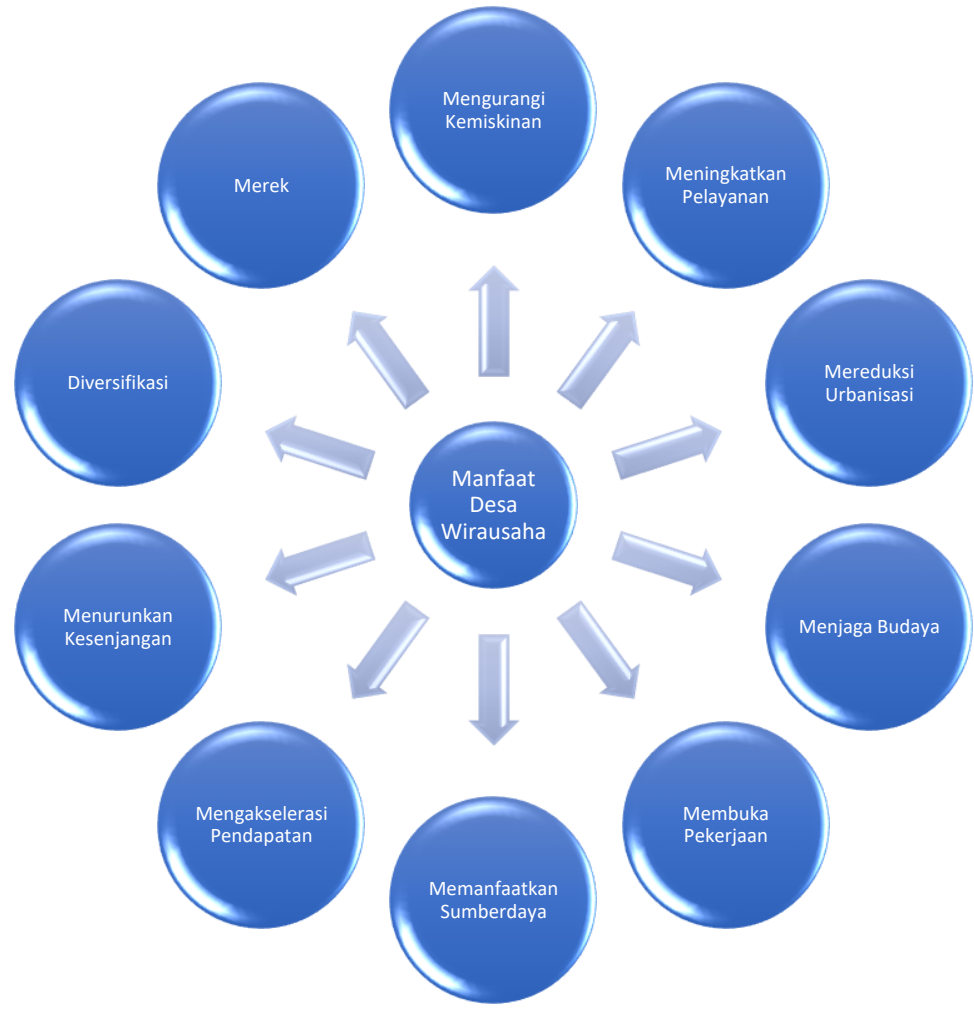

Gambar 1: Manfaat Desa Wirausaha 


\section{Peran BUMDes bagi Desa Wirausaha}

Keberadaan BUMDes memerankan beberapa fungsi secara langsung maupun tidak langsung bagi implementasi desa wirausaha (Kusuma and Purnamasari, 2016), yaitu untuk:

1. Mendistribusikan segenap inisiatif masyarakat suatu desa;

2. Mengeksplotasi sumber daya manusia atau warga desa yang dikelolaan secara bijaksana dan ramah lingkungan;

3. Membangun potensi suatu desa;

4. Mengenali dan mengeksplorasi kekayaan sumber daya alam suatu desa;

5. Menyertakan dan menyerahkan kapital dari pemerintah desa dalam format permodalan serta aset desa guna dikelola manajemen BUMDes.

\section{Strategi Desa Wirausaha}

Ada beberapa strategi yang dapat dikerjakan guna mewujudkan gagasan desa wirausaha (Purnomo, Putri and Rosyidah, 2017; Hilman, 2018), yaitu:

1. Peningkatan kualitas sumberdaya manusia;

2. Pengembangan kuantitas dan kualitas alat produksi;

3. Pembangunan struktur kelembagaan wirausaha;

4. Pengembangan kualitas layanan aparatur desa;

5. Peningkatan pemasaran desa wirausaha;

6. Pengembangan kualitas infrastruktur yang representatif; serta

7. Penyiapan karakter dan dukungan masyarakat desa.

\section{Pengembangan Desa Wirausaha}

Ada beberapa tindakan dan langkah yang dapat dilakukan dalam membangun dan mengembangkan desa wirausaha (Business Jargons, 2021), diantaranya yaitu:

1. Ketersediaan Bahan Baku

Untuk pendirian industri apapun, ketersediaan bahan baku yang memadai merupakan suatu keharusan. Namun demikian, ketiadaan bahan baku serta 
mahalnya bahan baku telah melemahkan pertumbuhan industri tersebut. Selama bertahun-tahun, telah diamati bahwa industri pedesaan yang memiliki bahan baku berat yang diproduksi di daerah pedesaan itu sendiri, seringkali bertahan dalam jangka panjang. Oleh karena itu, wirausahawan pedesaan harus dipastikan mendapatkan pasokan bahan baku yang layak.

2. Penyiapan Sumber Keuangan

Untuk memulai dan menjalankan industri dengan lancar dan tanpa gangguan di daerah pedesaan, keuangan bertindak sebagai bahan bakar. Ketersediaan dana pada saat dibutuhkan, dengan tingkat bunga yang wajar, merupakan syarat utama yang harus dipenuhi. Untuk tujuan ini bank dan lembaga keuangan dapat memfasilitasi agar dapat menghilangkan kendala yang disebabkan karena kurangnya keuangan.



Gambar 2: Pengembangan Desa Wirausaha 
3. Pusat Produksi sekaligus Pemasaran

Pusat produksi sekaligus pemasaran perlu dibangun dengan teknologi digital mutakhir dan fasilitas infrastruktur yang canggih di daerah dengan tingkat produksi dan pertumbuhannya tinggi. Ini mendorong bisnis ekspor serta mempertemukan pembeli dan penjual, dan menghilangkan perantara.

4. Pengembangan Sikap Wirausaha

Apabila pengusaha kurang memiliki bakat dan kompetensi, maka akan membuat unit industri beroperasional tidak sehat. Untuk itu perlu dikembangkan sikap dan kompetensi kewirausahaan di kalangan calon wirausaha melalui program pelatihan kewirausahaan.

5. Pendidikan Wirausaha

Untuk menanamkan keterampilan kewirausahaan, sikap dan ketajaman pada pemuda, pendidikan kewirausahaan harus diberikan sejak di sekolah, perguruan tinggi dan universitas. Ini akan membentuk dan mengarahkan pikiran-pikiran pemuda untuk bekerja atau berkarir di bidang tersebut.

6. Kesadaran

Pada dasarnya tidak tersedianya fasilitas bukanlah masalah yang besar. Namun, permasalahan yang terbesar adalah belum adanya kesadaran akan fasilitas yang tersedia untuk pengembangan wirausaha pedesaan. Untuk itu perlu dilakukan upaya agar masyarakat mengetahui fasilitas dan dukungan yang diberikan kepada para pengusaha, untuk membantu mereka dalam mendirikan industri di pedesaan.

7. Pelatihan Kelembagaan

Fasilitas harus dibuat untuk memberikan pelatihan kelembagaan yang dapat mengarahkan pengusaha dalam menghasilkan produk dan perdagangan sehingga sumber daya daerah dapat dimanfaatkan dengan sebaik mungkin.

\section{Jenis Desa Wirausaha}

Pengembangan desa sebagai aset wirausaha dapat dikelompokkan dalam beberapa jenis desa wirausaha (Javandira, Purnomo and Rosyidah, 2018; Setiyadi, 2019; Purnomo et al., 2020; Siregar et al., 2020; Sutiksno et al., 2020; Business Jargons, 2021) sebagai berikut. 


\section{Agrokompleks}

Seperti namanya, wirausaha jenis ini memanjakan diri dalam penjualan langsung atau pengolahan produk pertanian, misalnya padi, jagung, gula, produk susu, rempah-rempah, minyak sayur, gula merah, dan lainnya.

2. Industri Berbasis Hutan

Industri yang bergerak dalam penyediaan kayu atau produk kayu, industri sabut, pembuatan madu, produk bambu, dan lainnya tercakup dalam industri berbasis hutan.

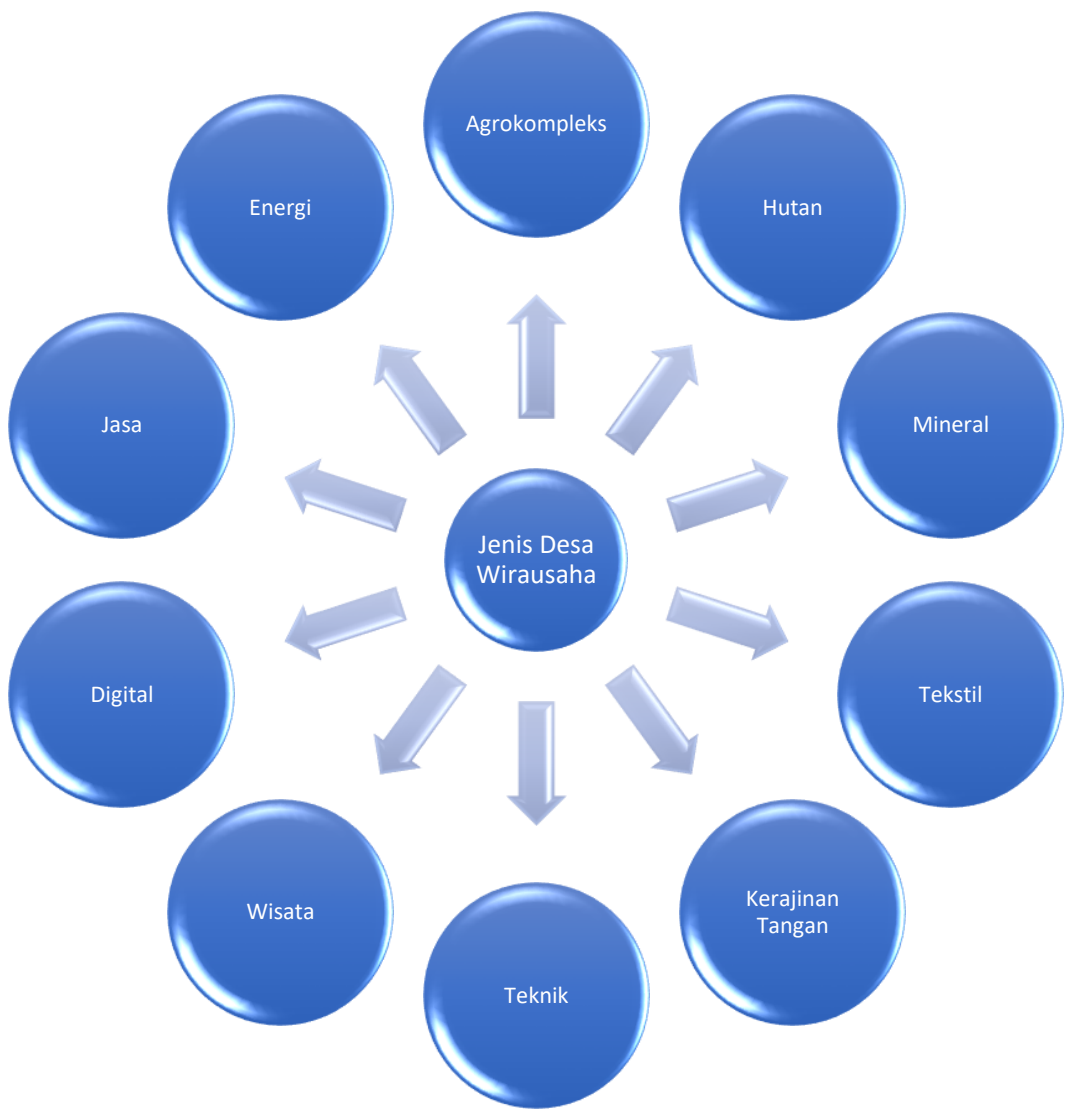

Gambar 3: Pengembangan Desa Wirausaha 
3. Industri Berbasis Mineral

Industri mineral meliputi industri semen, pemecah batu, serbuk pelapis dinding, dan lainnya termasuk dalam industri berbasis mineral.

4. Industri Tekstil

Industri berupa tenun, pemintalan, ikat dan pewarna, pewarnaan dan pemutihan tekstil termasuk dalam kategori ini.

5. Kerajinan Tangan

Barang kerajinan atau artistik yang terbuat dari kayu, bambu, kaca, rami, tanah, dan semacamnya disebut sebagai kerajinan tangan. Selain itu, barangbarang dekorasi tradisional, mainan, barang antik dan lainnya juga tercakup di sini.

6. Layanan Teknik

Wirausaha ini meliputi alat dan perlengkapan yang digunakan dalam pertanian seperti traktor, pompa, pipa dan perlengkapan, perbaikan, dll.

7. Wisata

Wirausaha berbasis komunitas atau masyarakat yang berdayakan wisata di suatu wilayah menggunakan akselerasi elemen atraksi, fasilitas dan aksesibilitas. Biasanya berupa pemanfaatan keindahan alam untuk mendatangkan pengunjung.

8. Digital

Wirausaha yang menggunakan akses digital seperti sewa internet, website, toko online, market place, aplikasi dan ojek online.

9. Kuliner

Wirausaha yang membuat ragam produk pangan atau kuliner untuk memenuhi kebutuhan konsumsi masyarakat seperti kue, kerupuk, jajanan, dan lauk pauk.

10. Jasa

Wirausaha yang menyediakan beragam jasa seperti cuci baju, olahraga, pijat, dan kesehatan. 
11. Energi

Wirausaha yang berusaha mencukupi kebutuhan energi listrik suatu rumah tangga.

\section{Penelitian Kewirausahaan Desa}

Penelitian kewirausahaan di Indonesia terus memperlihatkan tren berkembang (Purnomo, Usman and Asitah, 2019). Begitu juga penelitian terkait kewirausahaan desa (rural entrepreneurship) terus tumbuh dan berkembang di tingkat global. Data Scopus memperlihatkan ada 263 publikasi yang mengulas tentang wirausaha Desa sejak tahun 1976 hingga tahun 2020 (Purnomo and Rosyidah, 2021).

Documents by year

40

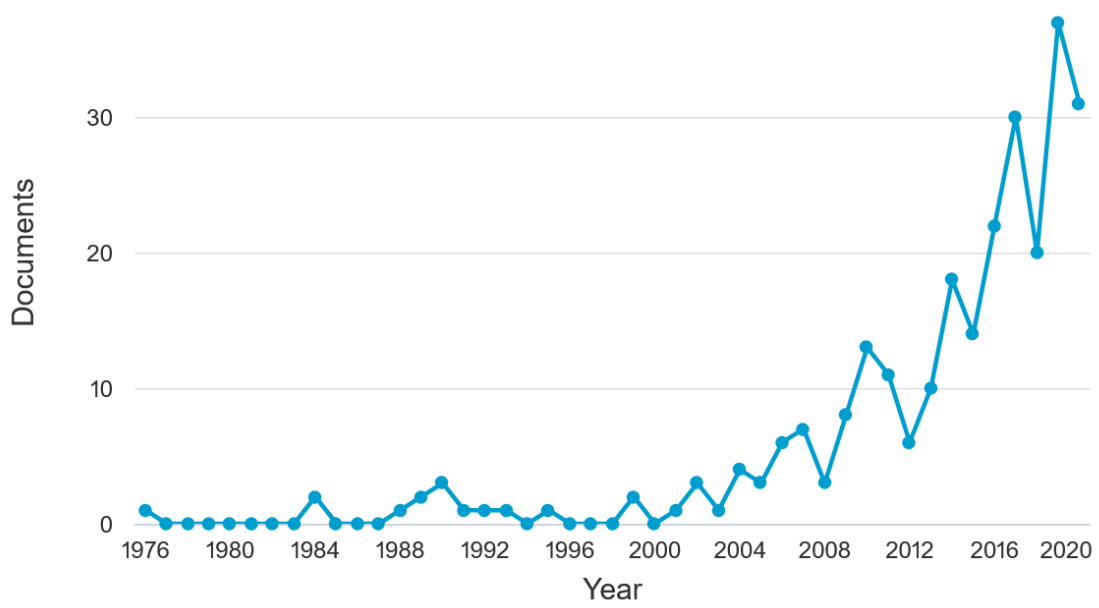

Gambar 4: Jumlah Penelitian Kewirausahaan Desa (Purnomo and Rosyidah, 2021) 


\section{References}

Ansari, B. et al. (2013) 'Sustainable Entrepreneurship in Rural Areas', Research Journal of Environmental and Earth Sciences, 5(1), pp. 26-31. doi: 10.19026/rjees.5.5635.

Bachrein, S. (2016) 'Pendekatan Desa Membangun di Jawa Barat: Strategi dan Kebijakan Pembangunan Perdesaan', Analisis Kebijakan Pertanian, 8(2), p. 133. doi: 10.21082/akp.v8n2.2010.133-149.

Business Jargons (2021) Rural Entrepreneurship, Business Jargons. Available at: https://businessjargons.com/rural-entrepreneurship.html (Accessed: 19 February 2021).

Fitriyani, Y. et al. (2018) 'Menggerakkan Ekonomi Desa Melalui Badan Usaha Milik Desa (BUMDes)', Jurnal Pengabdian Kepada Masyarakat MEDITEG, 3(1). doi: 10.34128/mediteg.v3i1.35.

Hastuti, P. et al. (2020) Kewirausahaan dan UMKM. Medan: Yayasan Kita Menulis. Available at: https://kitamenulis.id/2020/03/02/kewirausahaan-danumkm/.

Hilman, I. (2018) 'Penetapan Desa Wirausaha dan Strategi Pengembangannya', JIMFE (Jurnal Ilmiah Manajemen Fakultas Ekonomi), 3(2), pp. 28-36. doi: 10.34203/jimfe.v3i2.644.

Javandira, C., Purnomo, A. and Rosyidah, E. (2018) Kamus Pertanian. Sidoarjo: UNUSIDA Press.

Kusuma, A. H. P. et al. (2020) Brand Management: Esensi, Posisi dan Strategi. Medan: Yayasan Kita Menulis. Available at: https://kitamenulis.id/2020/05/22/brand-management-esensi-posisi-danstrategi/.

Kusuma, H. and Purnamasari, N. (2016) Baseline Research Membangun Gerakan Desa Wirausaha. Yogyakarta.

Presiden Republik Indonesia (2016) 'Undang-Undang Republik Indonesia Nomor 6 Tahun 2014 Tentang Desa', Republik Indonesia. Jakarta.

Purnomo, A. et al. (2020) Dasar-Dasar Kewirausahaan: untuk Perguruan Tinggi dan Dunia Bisnis. Medan: Yayasan Kita Menulis. Available at: https://kitamenulis.id/2020/04/06/dasar-dasar-kewirausahaan-untukperguruan-tingi-dan-dunia-bisnis/. 
Purnomo, A., Putri, R. A. and Rosyidah, E. (2017) Kamus Manajemen Sumber Daya Manusia. Sidoarjo: UNUSIDA Press.

Purnomo, A. and Rosyidah, E. (2021) Research Dataset of The Rural Entrepreneurship (1976-2020), Mendeley Data. Available at: https://data.mendeley.com/datasets/kw2jypm3cv/1.

Purnomo, A., Usman, I. and Asitah, N. (2019) 'Penelitian Kewirausahaan di Indonesia : Pemetaan Publikasi dalam Perspektif Scientometrik (1972-2019)', AdBispreneur, 4(3), p. 207. doi: 10.24198/adbispreneur.v4i3.25021.

Puspitasari, D. C. (2018) 'Wirausaha Muda Membangun Desa: Dinamika Partisipasi Pembangunan Desa', Jurnal Studi Pemuda, 4(2), p. 330. doi: 10.22146/studipemudaugm.36817.

Saputra, D. H. et al. (2020) Digital Marketing: Komunikasi Bisnis Menjadi Lebih Mudah. Medan: Yayasan Kita Menulis. Available at: https://kitamenulis.id/2020/02/26/digital-marketing-komunikasi-bisnismenjadi-lebih-mudah/.

Setiyadi, Y. (2019) Pengertian Desa Wisata dan Konsep Pengembangannya, Ensiklo. Available at: https://ensiklo.com/2019/10/21/pengertian-desa-wisata/ (Accessed: 18 February 2021).

Siregar, D. et al. (2020) Technopreneurship: Strategi dan Inovasi. Medan: Yayasan Kita Menulis. Available at: https://kitamenulis.id/2020/04/13/technopreneurship-strategi-dan-inovasi/.

Sutiksno, D. U. et al. (2020) Tourism Marketing. Medan: Yayasan Kita Menulis. Available at: https://kitamenulis.id/2020/05/12/tourism-marketing/.

Thakur, S. (2021) Rural Entrepreneurship: Meaning, Types and Importance, What is Enterpreneurship. Available at: https://101entrepreneurship.org/ruralentrepreneurship/ (Accessed: 20 February 2021). 